\title{
L'illustrazione di moda tra arte, comunicazione e progetto
}

\author{
Stefano Chiarenza
}

Abstract

L'illustrazione di moda costituisce una delle più significative forme di comunicazione visiva di modelli estetici legati alla produzione di abbigliamento. In tale settore, la capacità del disegno di innescare processi di modificazione di codici sociali, attraverso la propagazione su scala collettiva di fenomeni culturali correlati al vestiario, lo rendono elemento chiave nella costruzione dell'identità estetica. La sinergia diretta tra artista e osservatore nonché la relazione tra il disegno e prefigurazione progettuale, fanno infatti dell'illustrazione di moda una espressione artistica a cavallo tra comunicazione e progetto.

La rappresentazione della moda definisce inoltre, mediante immagini, degli ideali. Figure, colori, oggetti, indumenti disegnati comunicano visivamente parte di un immaginario sociale fondato, in una sorta di entropia semiotica, anche di parole e simboli.

II presente contributo indaga sulle modalità di illustrazione degli ultimi due secoli. Esaminando una letteratura che si estende su diversi ambiti culturali, ripercorre le diverse declinazioni dell'illustrazione di moda evidenziando il valore del disegno di moda quale forma di arte e al tempo stesso quale potente strumento di comunicazione in grado di influenzare, in modo evidente, le scelte e i gusti delle diverse classi sociali.

\section{Parole chiave}

figurino, moda, comunicazione visiva, fashion concept, illustrazione.

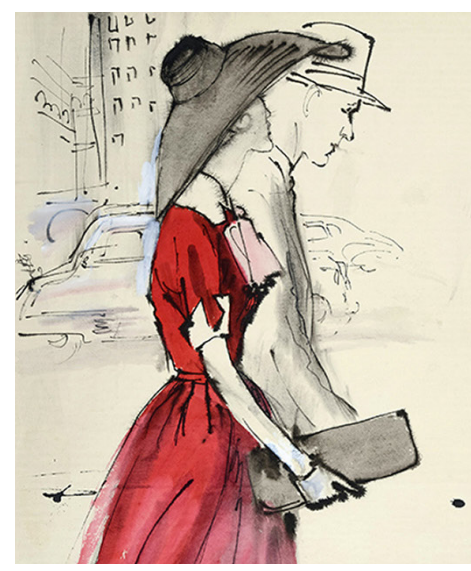




\section{Introduzione}

L'illustrazione di moda costituisce una delle molteplici categorie di un linguaggio che trova il suo comune denominatore nel disegno. All'interno della varia e complessa fenomenologia di tale sistema espressivo, questa si contraddistingue non solo per il suo carattere eminentemente descrittivo che conduce volutamente l'osservatore a uno specifico interesse per il contenuto e alla quasi naturale formulazione di un giudizio estetico, ma anche per la sua capacità di configurarsi come pensiero progettuale (design thinking). Caratteristica quest'ultima che sottrae a tale forma di disegno la pura finalità descrittiva. In linea generale l'illustrazione, qualunque sia la sua natura, si muove all'interno di specifici domini contestuali: dell'informazione, della narrazione, dell'identità, del commento e della persuasione. I confini di tali contesti appaiono spesso sovrapposti ma sono tutti accomunati dal tono narrativo del linguaggio visivo utilizzato. $E$ in ciò è riconoscibile una significativa assonanza con il linguaggio verbale [Barthes 1990]. Ciò che dunque distingue un tipo di illustrazione da un'altra è la conoscenza, da parte di chi usa tale comunicazione, di un preciso campo della scienza o della cultura.

Nella sfuggente distinzione tra le diverse categorie dell'illustrazione, quella di moda, pur mantenendo il comune denominatore narrativo-descrittivo e i caratteri dell'effimerità e della riproducibilità, si distingue per la sua capacità di interferire nella costruzione dei codici estetici del costume. Oltre a offrire un racconto visivo, pone infatti accenti importanti sulla persuasione e sulla determinazione di una precisa opinione, il che corrisponde alla costruzione di specifici orientamenti nel sentire e nell'agire, ovvero alla definizione di una tendenza. Le illustrazioni di moda hanno dunque partecipato in ogni epoca storica al cambiamento di orientamenti sociali e culturali, ponendosi come vere e proprie dichiarazioni estetiche di un periodo e, anche se molte volte lontane da quanto effettivamente prodotto e indossato, ci informano sulle differenze culturali e sulle aspirazioni sociali.

Ed è per questo che non è possibile quindi leggere l'illustrazione di moda al di fuori di un particolare contesto che resta elemento fondamentale per comprenderne la rilevanza e l'importanza come mezzo di comunicazione visiva. In altre parole "It influences the way we are informed and educated, what we buy and how we are persuaded to do things. It gives us opinion and comment. It provides us with entertainment and tells us stories" [Male 2017].

Alla luce di tali considerazioni, e sulla base della letteratura parcellizzata in pubblicazioni di diversa natura, il contributo ripercorre l'evoluzione negli ultimi due secoli dell'illustrazione di moda e del valore del disegno come strumento di comunicazione di modelli estetici.

Fig. I. Andy Warhol, Female fashion figure, Foundation for the Visua Arts, Inc.

Fig. 2. Tony Viramontes, Chanel Suite, 1986 Immagine tratta da $<$ www.tonyviramontes. com> (consultato il 25 febbraio 2021).
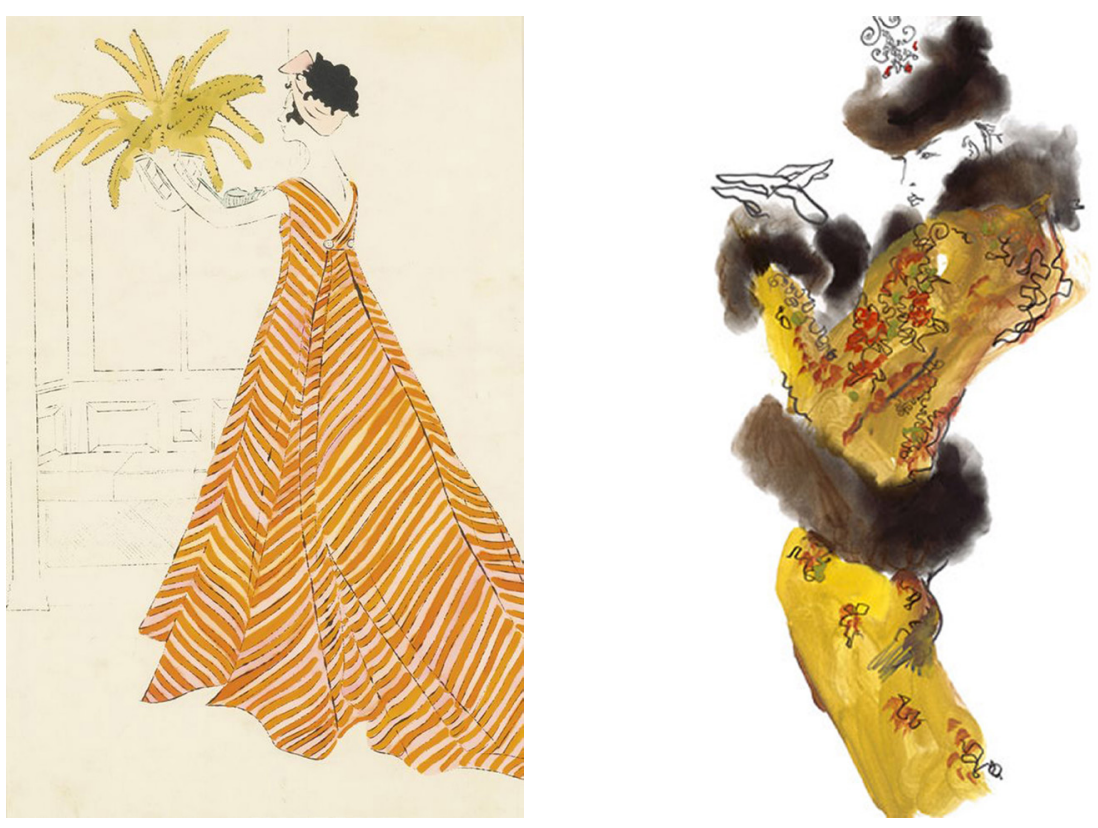


\section{L’illustrazione di moda. Un disegno dalle diverse anime}

Tra i vari campi dell'illustrazione, dunque, quella della moda appare strettamente correlata a due diversi ambiti della comunicazione. Da un lato quello legato alla divulgazione, alla promozione e alla vendita, dall'altro quello di tipo più strettamente progettuale, demandato alla filiera di realizzazione di un prodotto.

Tali orientamenti, tuttavia, appaiono ancorati a uno stesso filo conduttore, ovvero quello della espressione, che mette a stretto contatto arte e illustrazione fondendone spesso gli intenti e sfumando le artefatte categorizzazioni che ne distinguono le finalità. Non è improbabile, infatti, imbattersi in artisti che hanno disegnato illustrazioni di moda o in illustratori o designer della moda la cui forza narrativa ha sforato i limiti della comunicazione in pura espressività artistica (fig. I).

E la centralità dello studio della figura umana appare di certo un elemento di congiunzione tra arte e illustrazione di moda. L'attenzione alle proporzioni, la ricerca sulla forma delle membra e sull'articolazione delle parti in movimento, la rielaborazione dei canoni con applicazione di effetti di correzione ottica, se non di voluta distorsione, fanno oscillare sempre il disegno della figura tra orientata descrizione e pura espressione [Danielson 1989].

La rappresentazione del figurino, così come il disegno di oggetti o accessori di moda, diviene territorio di esercizio sul quale si sono misurati molteplici illustratori che hanno trovato occasioni artistiche anche negli intenti divulgativi e di promozione.

Segni e disegni dalle differenti anime e dalle variegate finalità vengono racchiusi dunque in un unico ambito così strettamente legato all'evoluzione del gusto da caratterizzare ampi contesti culturali nelle diverse epoche storiche (fig. 2).

Sebbene le illustrazioni di moda siano state in ogni epoca un'efficace forma di espressione e comunicazione sociale, il XIX secolo rappresenta per l'illustrazione un secolo fondamentale. In tale periodo, infatti, lo sviluppo tecnologico consente a questa singolare forma espressiva di assumere per la prima volta un ruolo chiave nella diffusione di modelli culturali. Le

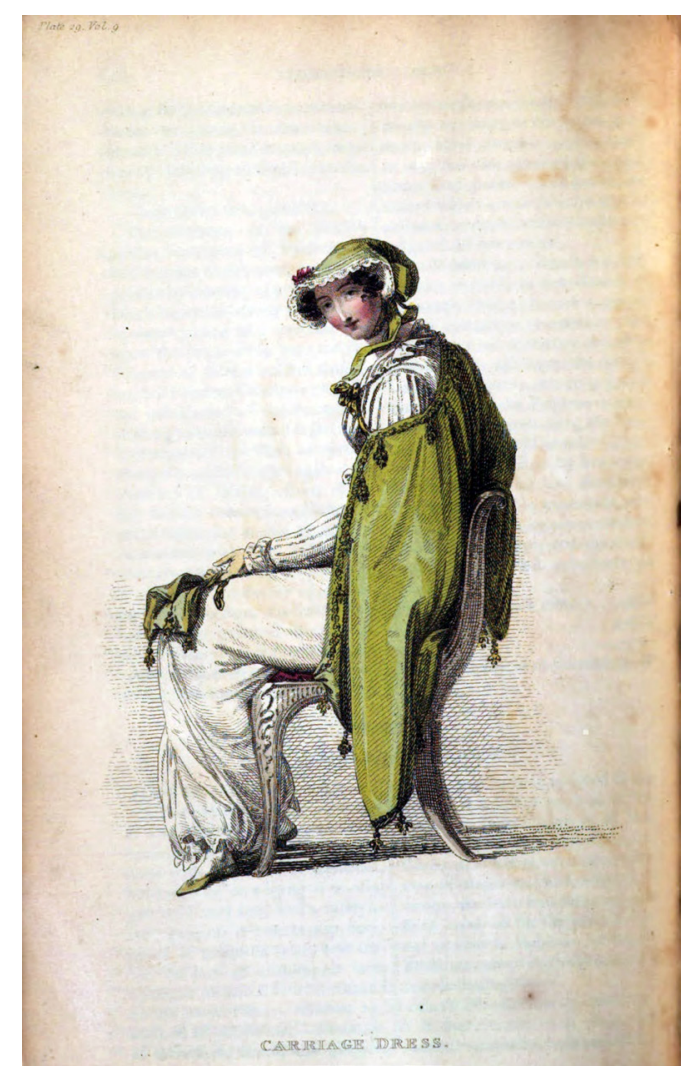


conoscenze acquisite nei vari ambiti del sapere, dalle scienze umane a quelle applicate, dalle scienze matematiche a quelle artistiche, trovano spazio sempre più ampio di diffusione attraverso la stampa. L'affermarsi di nuove tecniche dell'incisione su acciaio e della litografia, che permettono tirature numericamente elevate e la conseguente produzione di pubblicazioni periodiche, determina un inesplorato e fecondo territorio di sviluppo per l'illustrazione che diviene, in breve tempo, una delle modalità più utilizzate per la divulgazione [Anderson 1992, Brown 2002]. Disegni dalla precisione minuziosa appaiono in enciclopedie, saggi, riviste della più svariata natura e caratterizzate tanto da finalità educative quanto scientifiche. Come è stato opportunamente notato "nel corso del XIX secolo l'illustrazione scientifica conseguì esiti di singolare interesse sia sul piano propriamente qualitativo, per la straordinaria maestria con cui furono eseguite e riprodotte le immagini, sia per i risultati divulgativi che ne conseguirono: ogni genere d'informazione fu infatti spesso affiancata da spettacolari corredi figurativi a sostegno dell'espressione verbale del messaggio trasmesso" [De Rubertis $20|6, \mathrm{p} .8|$ ]. Ma non è soltanto la scienza a giovarsi dell'illustrazione. Il campo della moda trova infatti nel disegno a stampa un mezzo di diffusione delle nuove istanze culturali legate al costume che non ha precedenti nella storia. I progressi nella capacità e rapidità della riproduzione dell'immagine e la nascente cultura del consumo convertono l'illustrazione di moda da costoso ornamento a componente cruciale della comunicazione di modelli estetici. I periodici concorrono alla determinazione di una cultura di massa, includendo in essa la molteplicità degli strati sociali, e impongono ai lettori dei precisi orientamenti. II ricorso alle illustrazioni diventa funzionale a trasmettere interessi sociali, politici e commerciali degli editori, richiamando abilmente l'attenzione dei lettori su dettagli rilevanti. La comunicazione dell'illustrazione di moda comincia ad apparire strettamente connessa a fini puramente commerciali. Le riviste a stampa, infatti, contribuiscono in modo deciso alla diffusione e al dibattito su prodotti e tendenze: da profumi e cosmetici a scarpe, lingerie, gioielli e abiti -

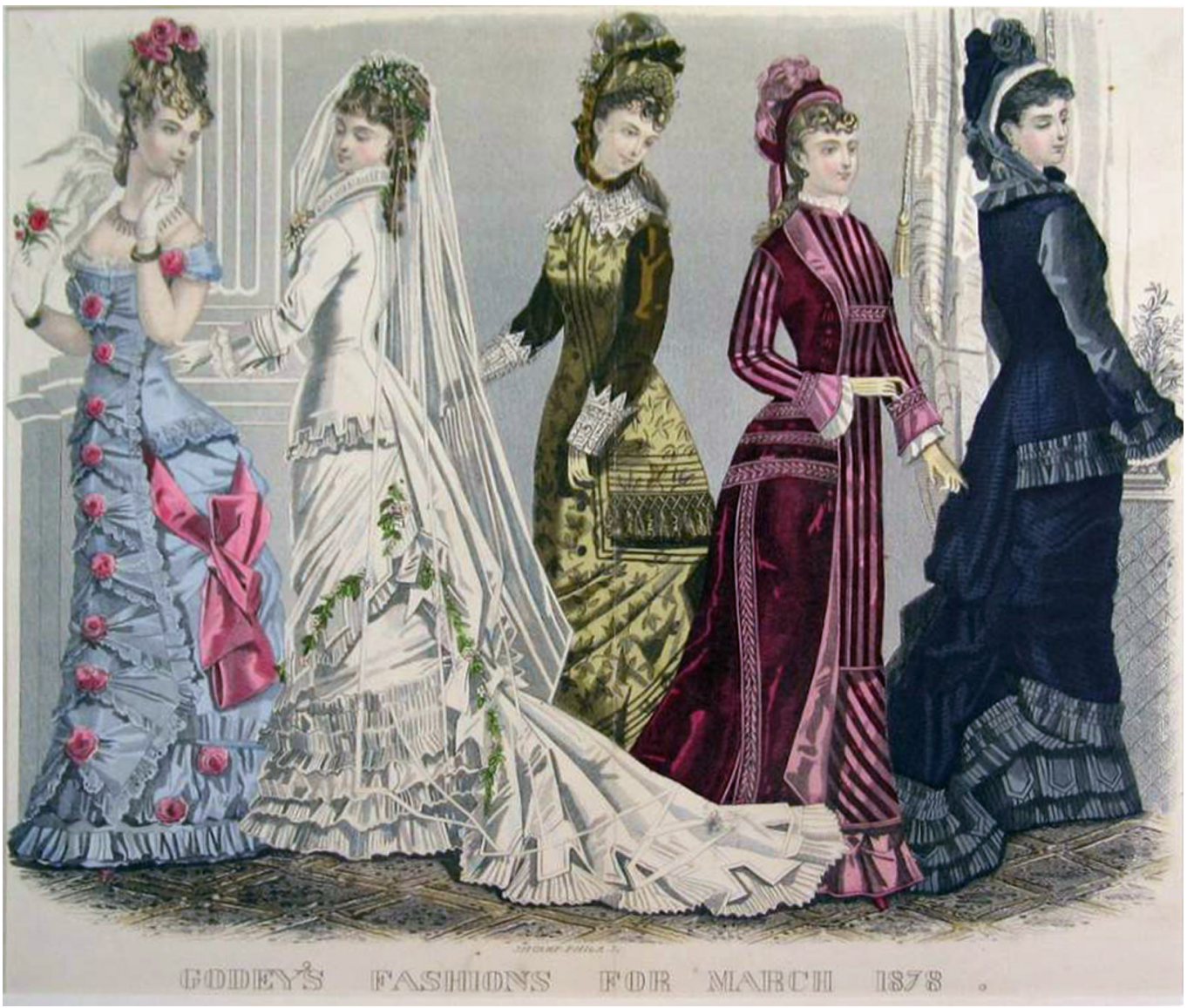


solo per citare alcuni tra i principali soggetti - fino a indagini antropologiche e teorie sartoriali. E questo è un elemento che dà impulso alla genesi di un interesse all'acquisto. Le illustrazioni passano da sagome e pose stereotipate a silhouette dalle posture sempre più studiate, con viste frontali, da dietro e di profilo [Simon 1995, p. 173], in stampe litografate prima in bianco e nero poi anche a colori [Coleman 1990]. L'attenzione alla rappresentazione delle donne diventa particolarmente significativa in quanto portatrice di una femminilità idealizzata rivolta in particolare alle donne lavoratrici [Anderson 1992]. Se si considera inoltre che il tempo di lettura di un testo e quello di una immagine si presenta molto diverso, a vantaggio di quest'ultima, resta chiaro quanto tale forma di comunicazione cominciasse a divenire dirompente, avvicinandosi a quella che nei secoli successivi sarebbe diventata l'anima del messaggio pubblicitario. La crescente importanza della comunicazione visuale nella moda rappresenta probabilmente il passaggio alla modernità [Stafford I99 I, Mirzoeff I999]. Lo sviluppo di nuove tecniche grafiche come l'incisione su rame, l'acquaforte, l'acquatinta e la stampa a pochoir costituiscono mezzi importantissimi per gli illustratori; immagini sempre più accattivanti faranno da vero e proprio acceleratore dell'industria della moda, rappresentando e allo stesso tempo promuovendo ciò che veniva indossato [Mackrell 1997, pp. 302, 303]. Ad amplificare il fenomeno comunicativo era, inoltre, la sempre maggiore diffusione di periodici specializzati (fig. 3). Da quelli dedicati in generale alla cultura e al costume, come l'Ackermann's Repository of Arts - periodico illustrato britannico di inizi '800 in cui la moda trova spazio accanto all'arte, la letteratura, il commercio, la manifattura e la politica - a edizioni di giornali incentrati solo sulla moda di cui La Belle Assembleé (Londra I806- I837), il Gode's Lady's Book (Philadelphia 1830-1878), Le Journal des dames et des modes [I] (Parigi | 798- | 839), Le Follet (Parigi I 829- I 892) sono solo alcuni tra quelli maggiormente significativi della società del tempo (figg. 4, 5). E offrono anche uno spaccato iconografico della cultura della moda di quegli anni, da un lato dedita alla tecnica sartoriale (Inghilterra), dall'altro alle tendenze stilistiche (Francia). Su questo aspetto si osserva anche come, quale elemento di assoluta novità, hanno inizio rappresentazioni di abiti e accessori che non illustrano più modelli esistenti, ma prefigurano elementi di novità influenzando in maniera decisa i desideri del pubblico e dando vita alle fantasie di evasione del lettore emulativo della classe media [Robinson 1997; Breward 2003]. Tra il finire del XIX e gli inizi del XX secolo il contenuto visivo delle riviste di moda diviene sempre più sofisticato. Come osservato da

Fig. 5. Illustrazione di moda, da Le Follet, 1856-1857, incisione a stampa su carta con colorazione a mano. <http://hdl.handle. net/I0934/RM000 I. (consultato il 25 febbraio 2021)

Fig. 6. James Tissot, Evening Fig. 6. James Issot, Evening
1878. Olio su tela. Parigi: Musée d'Orsay.
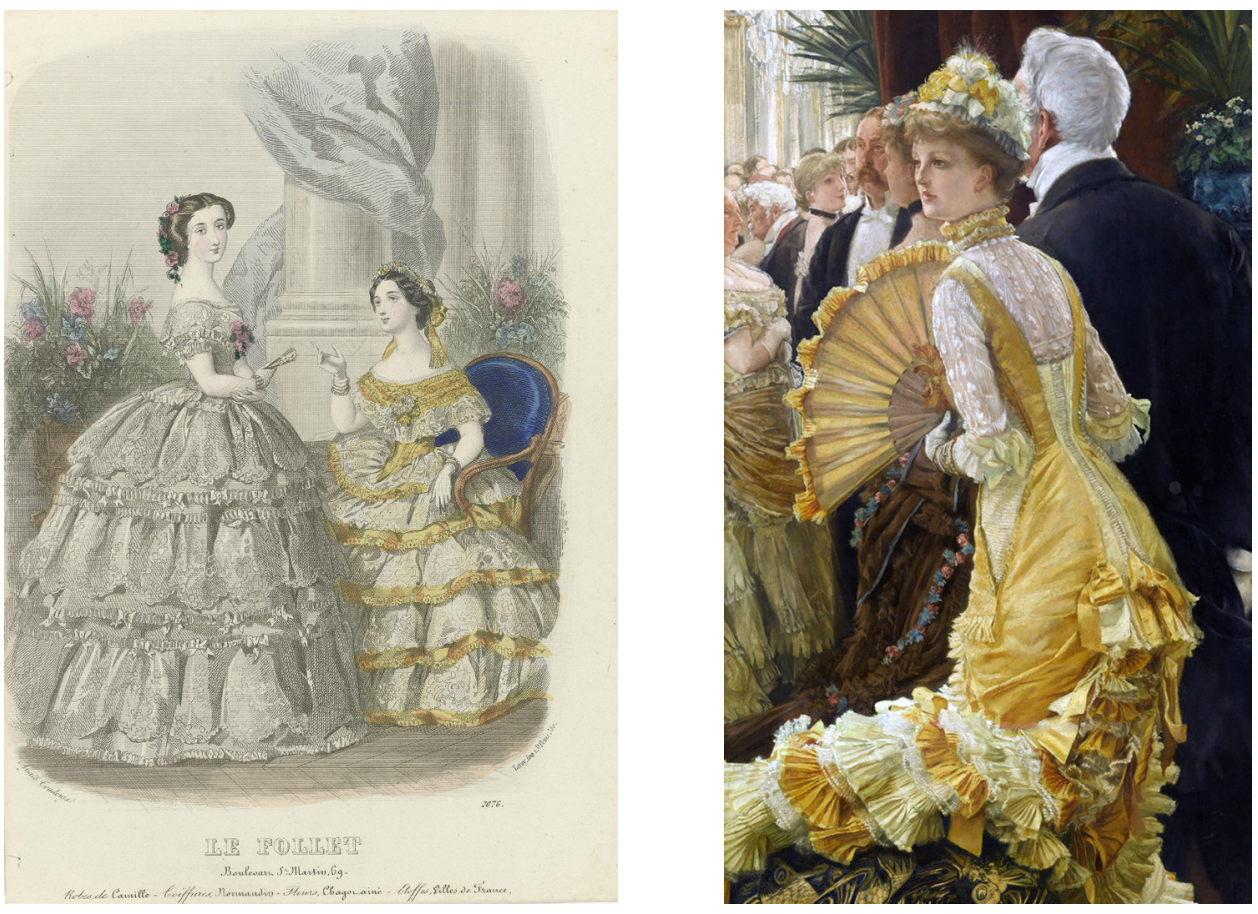
Fig. 7. Carl 'Eric' Erickson, Modella in tailleur grigio, inchiostro e gouache Immagine tratta da <https://www.graymca. com/collections/fashionillustration> (consultato 25 febbraio 2021).

Fig. 8. René Robert Bouché, Red Suit, 1950 acquerello e gouache su carta.
Breward "This is accompanied by a flowering of technical skill in élite publications before the incursions of photography and modernist aesthetics which were to define the nature of fashion illustration in the twentieth century" [Breward 2003, p. I20]. Se da un lato le riviste di massa offrivano un accesso relativamente economico a rappresentazioni di glamour alla moda, pur sacrificandone la qualità, dall'altro le pubblicazioni dell'alta società propagandavano immagini di lusso ricorrendo alla collaborazione con illustratori di chiara fama come Adolphe-Charles Sandoz ( 1845-c. 1925) o rinomati pittori quali ad esempio Jacques-Joseph Tissot ( 836 1902) o Alfred Stevens ( I 823-1906) (fig. 6). Atteggiamenti rivoluzionari caratterizzano invece la rappresentazione della moda nei decenni successivi. II riferimento principale delle illustrazioni erano le avanguardie della haute couture piuttosto che i contenuti commerciali delle figurazioni tradizionali. Nei primi decenni del $X X$ secolo le avanguardie figurative arti-
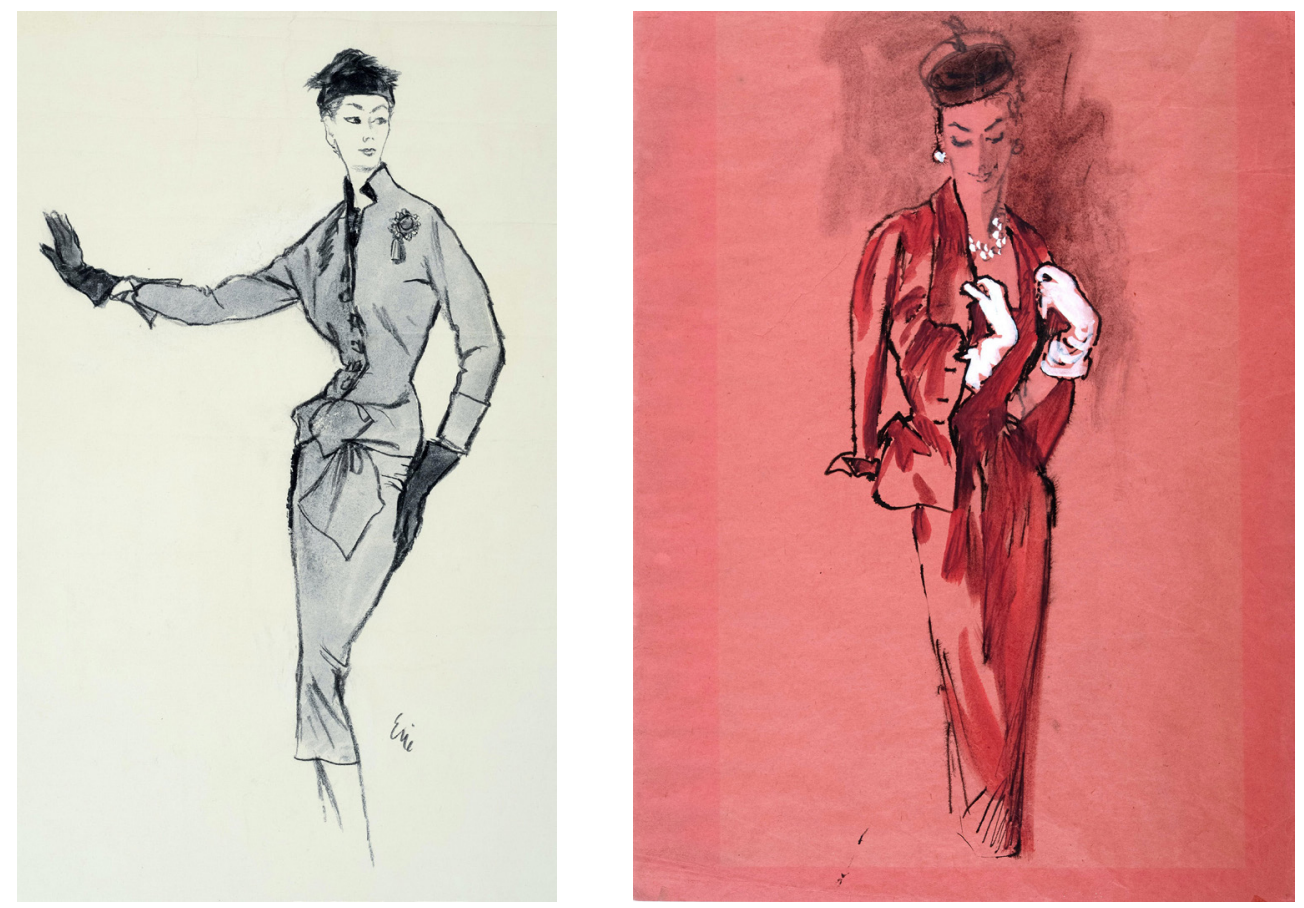

stiche interagiscono in maniera significativa con l'illustrazione di moda: il colore dei tessuti, la sagomatura delle vesti, le forma del corpo e i materiali utilizzati sono specchio delle correnti fauves, cubiste, espressioniste, futuriste, dadaiste e surrealiste [Barnes 1994]. Arte e illustrazione si trovano a essere in un contatto strettissimo. Ma la vera rivoluzione nel mondo della moda nel Novecento è apportata dalla fotografia. Già dalla fine dell'Ottocento alcuni periodici cominciano a sostituire per gli scopi promozionali le illustrazioni con immagini fotografiche a colori [Robinson 1997]. Ed è soltanto l'inizio della scalata della nuova tecnica. Infatti, se nei primi anni della sua storia l'illustrazione, in questo campo, ha avuto la finalità di registrare e comunicare le tendenze di moda, la crescente importanza data alla fotografia ne ridefinisce in qualche modo il ruolo, relegandola "al regno creativo del sogno" [Breward 2003, p. 122]. L'illustrazione di moda, sebbene fino agli anni ‘50-'60 mantenga ancora una certa rilevanza, grazie al talento di artisti quali Carl Oscar August Erickson (189|-1958) René Robert Bouché (1905-1963), André Édouard Marty (I882-1974), Eduardo Benito ( | 89 |-1981), Pierre Brissaud (1885-1964), René Bouët-Willaumez (1900-1979), Christian Bérard (1902-1949), (figg. 7-9) viene progressivamente offuscata dalla fotografia. Molti tra i più noti fotografi dell'epoca rivoluzionarono la rappresentazione della moda attraverso immagini che, attingendo alle esperienze artistiche delle avanguardie contemporanee, eviden- 
Fig. 9. Eduardo Benito, copertina illustrata per British Vogue, fine luglio 1926. Immagine tratta da <https://www.vogue. co.uk/fashion/gallery/ jewellery-images-vogue-archive> (consultato il 25 febbraio 2021 ). ziavano nuove identità tra abbigliamento e raffigurazione, in modo molto più efficace di quanto potessero fare le illustrazioni disegnate. Le immagini fotografiche riuscivano infatti a soddisfare le ricerca, da parte dell'industria della moda, di accentuare il potenziale immaginativo del lifestyle come strumento di promozione, e lo faceva con un linguaggio moderno in grado di anteporre il simbolismo alla materialità. Tra i periodici del tempo forse Vogue rappresenta l'esempio più significativo di questo passaggio [Breward 2003, Danielson I986].

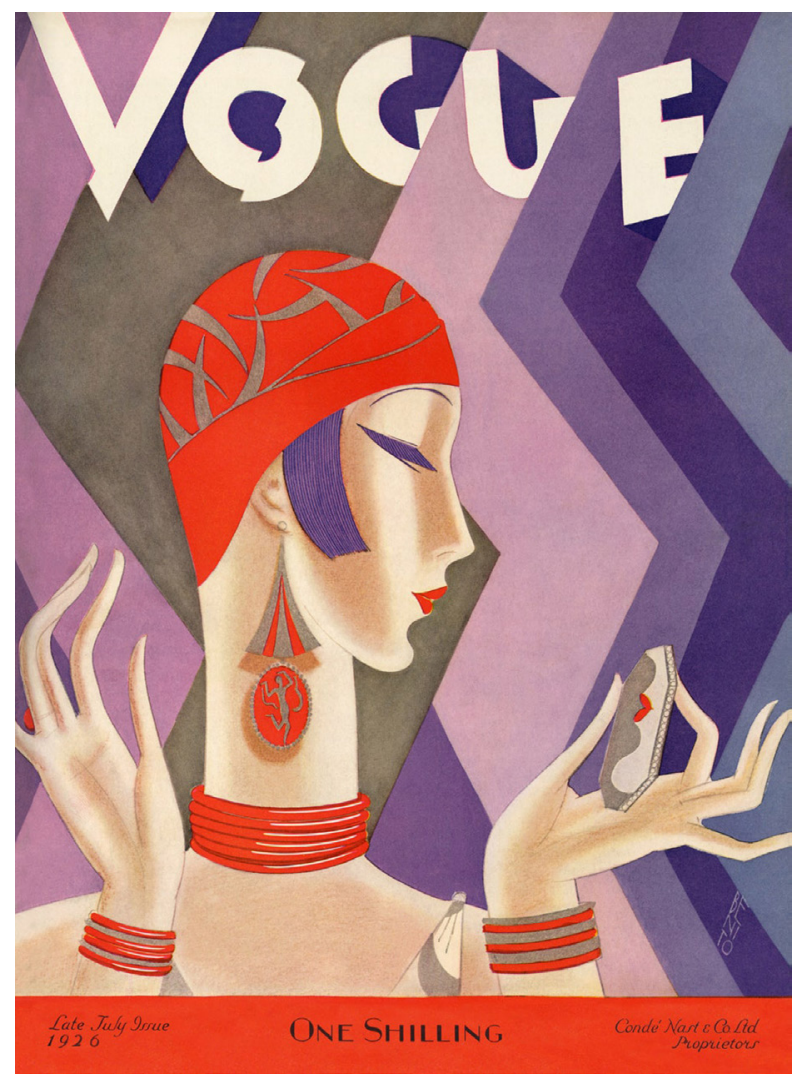

Edito alla fine dell'Ottocento negli Stati Uniti, agli inizi del Novecento trova ampia diffusione anche in Europa con redazioni in vari Paesi sostenendo l'idea della moda come fenomeno globale. Come Breward ha notato "Vogue capitalized on design innovations introduced in the production of European art magazines at the turn of the century, repackaging the fashion magazine as a desirable object in its own right, a harmonious and authoritative style guide that functioned as a bible for the fashion-conscious. Setting his horizons beyond the more parochial concerns of the old-style woman's magazine, Condé Nast looked to the philosophical and moral ideals of high modernism as a means of energizing the pages of his journal"' [Breward 2003, p. 123]. Riviste come Vogue e Harper's Bazaar smisero infatti di utilizzare disegni per le loro copertine e il lavoro degli illustratori a fini promozionali della moda viene sempre meno considerato. Come ha notato Packer "After 1963, only one artist was commissioned by Vogue with any regularity at all. This was [...] Antonio [Lopez] whose published work over all those years, still amounts to rather less than that of Eric or Bouché, or indeed any of Vogue's former regulars, in any normal working year" [Packer 1983, pp. 173, 174]. Benché si riscontri una mancanza di individualità nelle fotografie, appare palese che gli spazi dell'illustrazione sono ridotti (fig. I0), in parte per una mancanza di immaginazione da parte dei lettori, in parte per la capacità di immedesimazione insita nella fotografia: il consumatore non compra più dai disegni [Danielson 1986]. 


\section{Conclusioni}

Le illustrazioni di moda hanno rappresentato, nel tempo, una forma di espressione estetica che se da un lato ha affiancato le attività propriamente artistiche, dall'altro ha costituito una delle principali modalità di comunicazione di modelli estetici ad ampi gruppi sociali. L'impatto dei disegni di moda sulla vita quotidiana è stato senza dubbio significativo così come sorprendente appare la documentazione grafica prodotta nei secoli da artisti, illustratori e designer. L'impulso dato dall'illustrazione, tuttavia, non ha soltanto rappresentato una modalità di comunicazione e uno strumento di persuasione ma ha avuto spesso, attraverso la mano di disegnatori-artisti, anche la finalità di costruire il gusto, diventando essa stessa elemento fondamentale di prefigurazione progettuale. II lato espressivo dellillustrazione ha infatti importanti interazioni sia con il progetto che con la comunicazione e ha mostrato nella sua evoluzione storica la capacità di aprire a nuovi modi di guardare alla moda. Intuizione, creatività e immaginazione hanno caratterizzato, in altre parole, il pensiero creativo dell'illustrazione. Se l'avvento della fotografia ha costituito la rottura di un canale di comunicazione diretto tra disegno e consumatore, non ha tuttavia intaccato il valore dello stesso inteso quale pensiero progettuale. Ha però chiuso al fruitore la finestra dell'immaginazione a vantaggio di una realtà illusoria.

Il presente articolo ha inteso evidenziare le profonde relazioni tra disegno di moda, sviluppo tecnologico e comunicazione, sottolineando il contributo rilevante apportato da questa singolare forma di illustrazione alla storia della moda, del costume, ma anche a quella della sociologia e dell'antropologia culturale.

Fig. 10. Antonio Lopez, Couture Spring: The Mood for Evening is Sinuous, Vogue, marzo 1973. Immagine tratta da lmmagine tratta da chttps./Mww.vogue. com/article/antonio-lopez-1970s-sex-fashion-disco-documentary-by-james-crump > (consultato il 25 febbraio 202I).

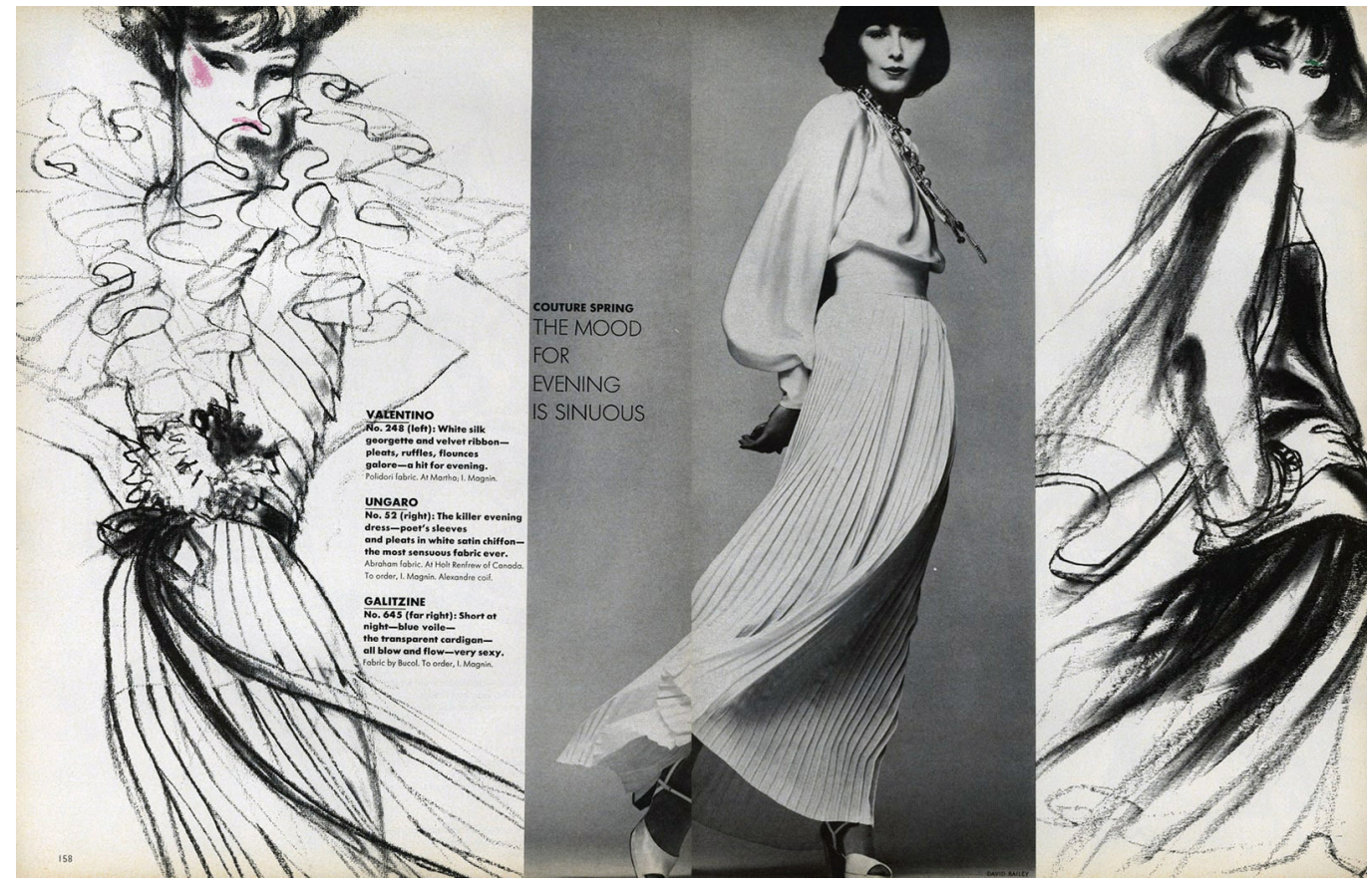

Note

[ I L Le Journal des dames et des modes, fondato nel 1797 ed edito a Parigi da Pierre La Mesangere, è stata una delle prime riviste periodiche illustrate. I repertori grafici, decantati dal poeta Baudelaire, furono spesso elaborati da rilevanti incisori e artisti come Horace Vernet ( I 789- | 836), Louis-Marie Lanté (I789- I87I) [Simon 1995; Best 2017]. 


\section{Riferimenti bibliografici}

Anderson P. (1992). The printed image and the transformation of popular culture, 1790- 1860. New York: Clarendon Press of Oxford University Press.

Barnes C. (1994). Fashion Illustration. London: Little, Brown \& Co.

Barthes R. (1990). The Fashion system. Berkeley \& Los Angeles: University of California Press

Best K. N. (2017). The history of fashion journalism. Norfolk: Bloomsbury Publishing.

Breward C. (2003). Fashion. Hong Kong: Oxford University Press.

Brown J. (2002). Beyond the lines: Pictorial reporting, everyday life, and the crisis of gilded age America. Berkeley and Los Angeles: University of California Press.

Coleman E. J. (1990). Fashions as Seen Through Fashion Plates. In Vintage Fashions, vol. I (2), pp. 48-53.

Danielson D. R. (1986). According to the artists: Professional fashion illustrators' views about their art form. In Clothing and Textiles Research Journal, vol. 5 (I), pp. 27-33.

Danielson D. R. ( 1989). The changing figure ideal in fashion illustration. In Clothing and Textiles Research Journal, vol. 8 (I), pp. 35-48.

De Rubertis R. (2016). For history of scientific illustration. The case of the People's Zoological Atlas by dr. Giovanni Boschi. In XY digitale, L'immagine nella scienza e nell'arte, n. 2, pp. 80-91.

Mackrell A. (1997). An illustrated history of fashion: 500 years of fashion Illustration. New York: Costume \& Fashion Press.

Male A. (2017). Illustration:A theoretical and contextual perspective. New York: Bloomsbury Visual Arts.

Mirzoeff N. (1999). An introduction to visual culture. London: Routledge.

PackerW. (1983). Fashion drawing in Vogue. New York: Coward McCann.

Robinson J. (1997). The fine art of fashion: an illustrated history. Sydney: Murdoch Books.

Simon M. (1995). Fashion in art. The Second Empire and Impressionism. London: Zwemmer.

Stafford B.M. (|99|). Body criticism: imaging the unseen in enlightenment art and science. London: MIT Press.

\footnotetext{
Autore

Stefano Chiarenza, Università San Raffaele Roma, stefano.chiarenza@uniroma5.it
}

Per citare questo capitolo: Chiarenza Stefano (2021). L'illustrazione di moda tra arte, comunicazione e progetto/Fashion Illustration between Art, Communication And Project. In Arena A., Arena M., Mediati D., Raffa P. (a cura di). Connettere. Un disegno per annodare e tessere. Linguaggi Distanze Tecnologie. Atti del $42^{\circ}$ Convegno Internazionale dei Docenti delle Discipline della Rappresentazione/Connecting. Drawing for weaving relationship. Languages Distances Technologies. Proceedings of the $42^{\text {th }}$ International Conference of Representation Disciplines Teachers. Milano: FrancoAngeli, pp. 4I 4-431. 


\title{
Fashion Illustration between Art, Communication and Project
}

\author{
Stefano Chiarenza
}

Abstract

Fashion illustration is one of the most significant forms of visual communication of aesthetic models related to the clothing production. In this sector, the ability of design to trigger processes of social codes modification, through the propagation on a collective scale of cultural phenomena related to clothing, make it a key element in the construction of aesthetic identity. The direct synergy between artist and observer as well as the relationship between drawing and planning foreshadowing make fashion illustration an artistic expression between communication and design. The fashion representation also defines ideals through images. Figures, colours, objects, garments designed visually communicate part of a social imaginary founded, in a sort of semiotic entropy, also of words and symbols. This contribution investigates the ways of illustration in the last two centuries. Examining the literature that extends over different cultural spheres, it traces the different declinations of fashion illustration, highlighting the value of fashion design as an art form and at the same time as a powerful communication tool capable of clearly influencing the choices and tastes of different social classes.

Keywords

fashion sketch, fashion history, visual communication, fashion concept, fashion illustration.

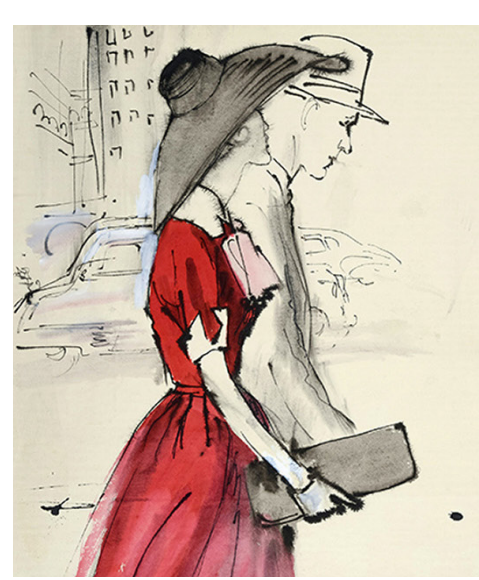




\section{Introduction}

Fashion illustration constitutes one of the many categories of a language that finds its common denominator in the drawing. Within the varied and complex phenomenology of this expressive system, this is distinguished not only by its eminently descriptive character which deliberately leads the observer to a specific interest in the content and the almost natural formulation of an aesthetic judgment but also for its ability to configure itself as design thinking. The latter feature removes the purely descriptive purpose from this form of drawing. In general, the illustration, whatever its nature, moves within specific contextual domains: information, narration, identity, comment and persuasion. The boundaries of these contexts often appear overlapping but they are all united by the narrative tone of the visual language used. And in this, we can recognize significant assonance with verbal language [Barthes 1990]. What therefore distinguishes one type of illustration from another is the knowledge, on the part of those who use such communication, of a specific field of science or culture. In the elusive distinction between the different categories of illustration, the fashion one, while maintaining the common narrative-descriptive denominator and the characteristics of ephemerality and reproducibility, stands out for its ability to interfere in the construction of the aesthetic codes of the costume. In addition to offering a visual story, it places important emphases on persuasion and the determination of a precise opinion, which corresponds to the construction of specific orientations in feeling and acting, or the definition of a trend. Fashion illustrations have therefore participated in every historical period in the change of social and cultural orientations, placing themselves as real aesthetic statements of a period and, even if many times far from what actually produced and worn, they inform us about cultural differences and social aspirations. For this reason, we cannot read the fashion illustration outside of a particular context which remains a fundamental element to understand its relevance and importance as a means of visual communication. In other words, "It influences the way we are informed and educated, what we buy and how we are persuaded to do things. It gives us opinion and comment. It provides us with entertainment and tells us stories" [Male 2017].

In light of these considerations, and based on the literature divided into publications of various kinds, the contribution traces the evolution over the last two centuries of fashion illustration and the value of drawing as a communication tool for aesthetic models.

Fig. I. Andy Warhol, Female fashion figure, Foundation for the Visua Arts, Inc.

Fig. 2. Tony Viramontes, Chanel Suite, 1986: <www.tonyviramontes. com> (accessed 2021, Febraury 25).
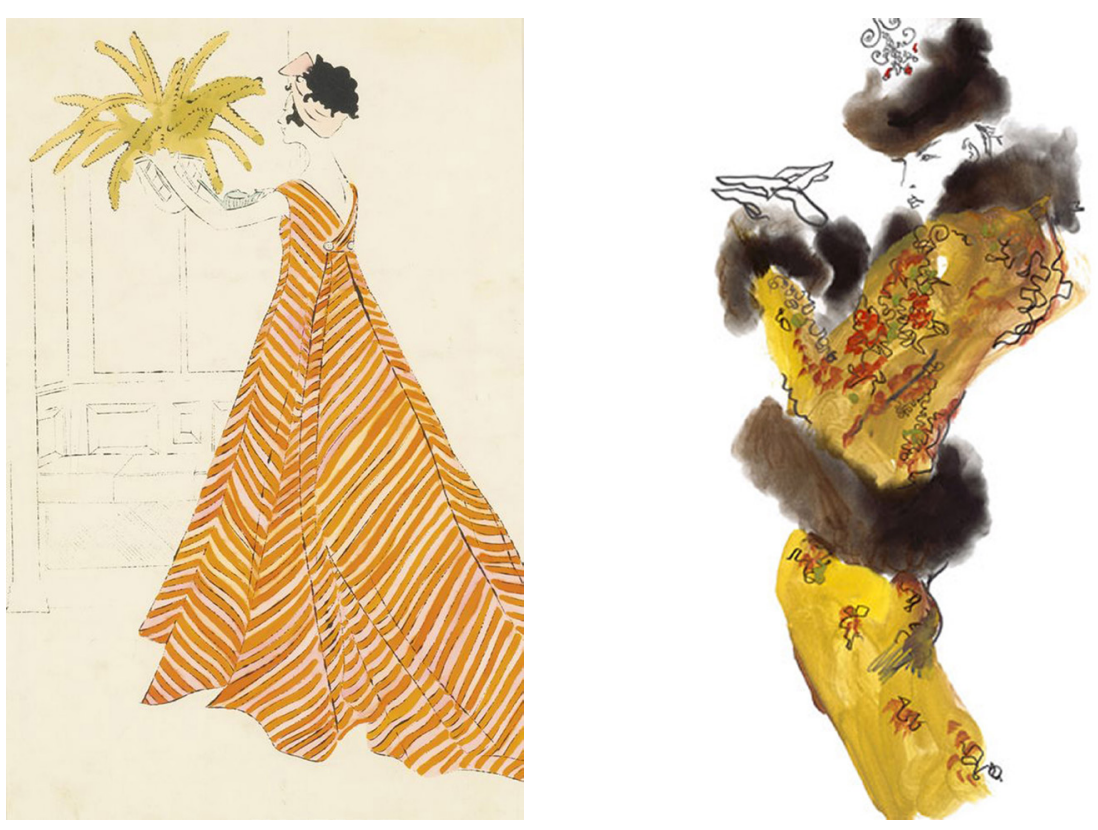


\section{Fashion illustration. A drawing with different souls}

Among the various fields of illustration, therefore, that of fashion appears closely related to two different areas of communication. On the one hand, that linked to disclosure, promotion and sale, on the other hand, that of a more strictly design type, delegated to the product chain.

However, these orientations appear to be anchored to the same common thread, namely that of expression, which puts art and illustration in close contact, often blending their intentions and blurring the artificial categorizations that distinguish their purposes. It is not unlikely to come across artists who have drawn fashion illustrations or illustrators or fashion designers whose narrative force has pushed the limits of communication in pure artistic expression (fig. I).

And the centrality of the study of the human figure certainly appears to be an element of conjunction between art and fashion illustration. The attention to proportions, the research on the shape of the limbs and the articulation of the moving parts, the reworking of the canons with the application of optical correction effects, if not deliberate distortion, always make the drawing of the figure oscillate between oriented description and pure expression [Danielson 1989].The representation of the fashion sketch, as well as the drawing of objects or fashion accessories, becomes an exercise area on which many illustrators have measured themselves who have found artistic opportunities also in the dissemination and promotion intentions. Signs and drawings with different souls and varied purposes are therefore enclosed in a single area so closely linked to the evolution of taste that they characterize broad cultural contexts in different historical eras (fig. 2).

Although fashion illustration has been an effective form of social expression and communication in every era, the nineteenth century represents a pivotal time for illustration. In this period, technological development has allowed this singular form of expression to assume for the first time a key role in the dissemination of cultural models. The knowledge acquired

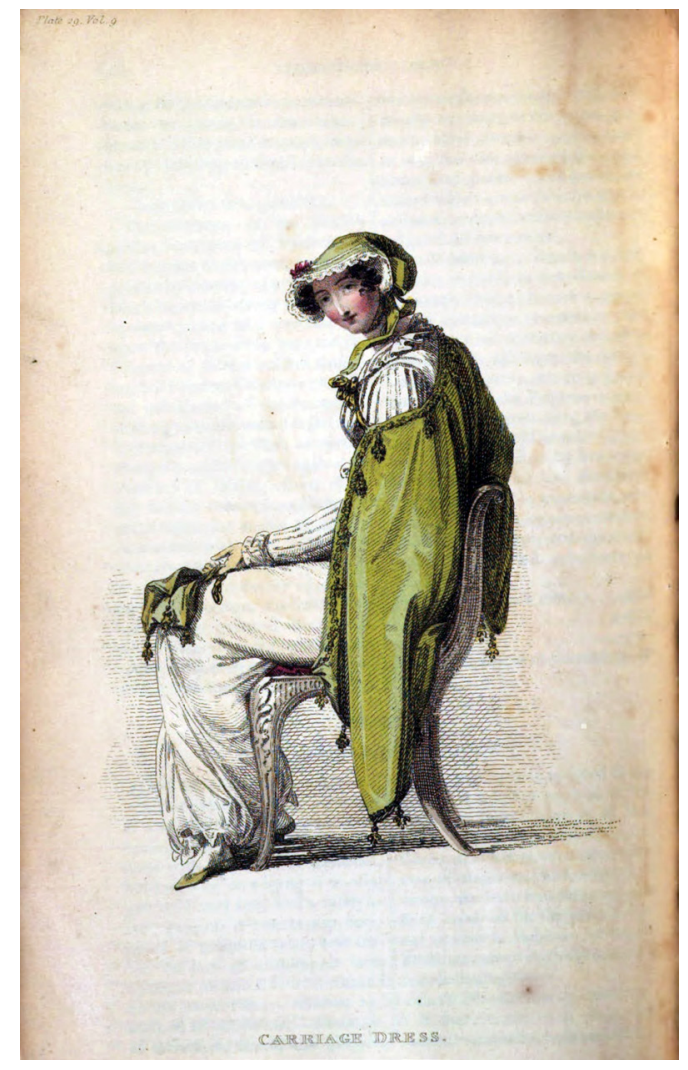


in the various fields of knowledge, from the humanities to the applied sciences, from the mathematical sciences to the artistic ones, find more and more space for diffusion through the press. The emergence of new techniques of engraving on steel and lithography, which allow numerically high print runs and the consequent production of periodical publications, determines an unexplored and fruitful territory of development for illustration which becomes, in a short time, one of the modalities most used for dissemination [Anderson 1992, Brown 2002]. Drawings with meticulous precision appear in encyclopedias, essays, magazines of the most varied nature and characterized by both educational and scientific purposes. As has been aptly noted, "during the nineteenth-century scientific illustration attained outcomes of singular interest both for the qualitative level, for the extraordinary skill with which the images were performed and reproduced, and for the informative results that ensued: every kind of information was in fact often flanked by spectacular figurative kits in support of the verbal message transmitted" [De Rubertis 20I6, p. 8I]. But it's not just science that benefits from illustration. The field of fashion finds in the printed drawing a means of spreading the new cultural instances linked to the costume that is unprecedented in history. Advances in the ability and speed of image reproduction and the nascent consumer culture convert fashion illustration from an expensive ornament to a crucial component of the communication of aesthetic models.

Periodicals contribute to the determination of mass culture, including in it the multiplicity of social classes, and impose precise guidelines on readers. The use of illustrations becomes functional to convey the social, political and commercial interests of publishers, skillfully drawing the attention of readers to relevant details. The communication of fashion illustration begins to appear strictly connected for purely commercial purposes. The printed magazines contribute decisively to the diffusion and debate on products and trends: from perfumes and cosmetics to shoes, lingerie, jewellery and clothes -just to name a few of

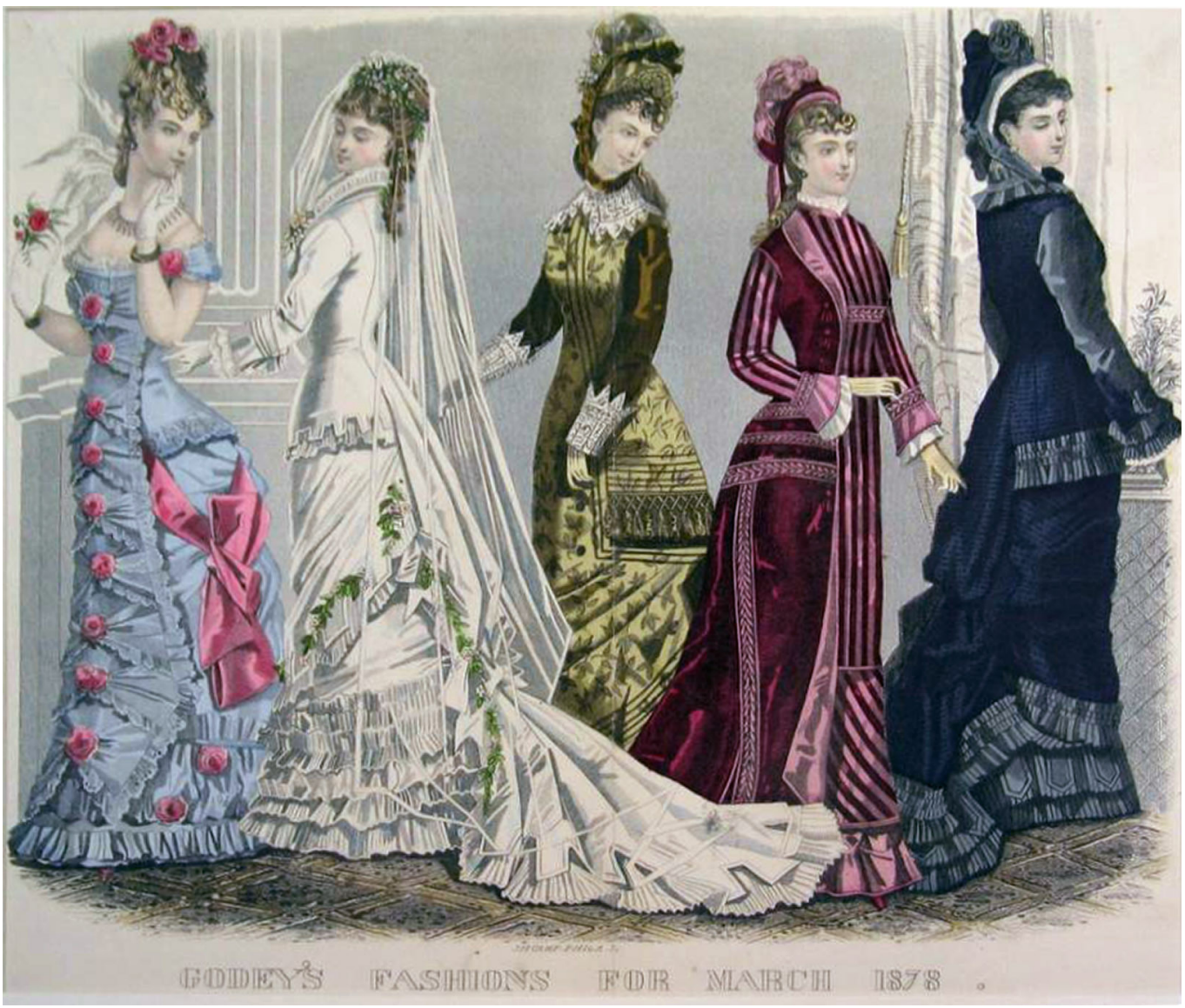


the main subjects- up to anthropological investigations and sartorial theories. And this is an element that gives impetus to the genesis of interest in buying. The illustrations move from stereotyped silhouettes to figures with increasingly studied postures, with front, back and profile views [Simon 1995, p. 173], in lithographed prints first in black and white then also in colour [Coleman 1990]. The attention to the representation of women becomes particularly significant as it is the bearer of idealized femininity aimed in particular at working women [Anderson 1992]. Furthermore, if we consider that the reading time of a text and that of an image is very different, to the advantage of the latter, it remains clear how much this form of communication began to become disruptive, approaching what it would have become in the following centuries the soul of the advertising message. The growing importance of visual communication in fashion probably represents the transition to modernity [Stafford 1991, Mirzoeff 1999]. The development of new graphic techniques such as copper engraving, etching, aquatint and pochoir printing are very important means for illustrators; increasingly captivating images will act as a real accelerator of the fashion industry, representing and at the same time promoting what was worn [Mackrell 1997, pp. 302, 303]. The communication phenomenon was also amplified by the increasing diffusion of specialized periodicals (fig. 3). From those dedicated, in general, to culture and costume, such as Ackermann's Repository of Arts -British illustrated periodical of the early 19th century in which fashion finds space alongside art, literature, commerce, manufacturing and politics- to editions of newspapers focusing only on fashion such as La Belle Assembleé (London I 806I837), Godey's Lady's Book (Philadelphia I830-1878), Le Journal des dames et des modes [I] (Paris 1798-1839), Le Follet (Paris 1829-1892) are just some of the most significant ones of the society of the time (figs. 4, 5). They also offer an iconographic insight into the fashion culture of those years, on the one hand, dedicated to sartorial technique (England), on the other to stylistic trends (France). On this aspect, we can observe how, as an element of absolute novelty, representations of clothes and accessories that no longer illustrate existing models are spreading. They foreshadow elements of novelty, decisively influencing the wishes of the public and giving life to the escape fantasies of the emulative middle-class reader [Robinson 1997, Breward 2003]. Between the end of the 19th and the beginning of the 20th century, the visual content of fashion magazines became increasingly sophisticated. As noted by Breward, "This is accompanied by a flowering of technical skill in élite publications

Fig. 5. Fashion illustration, from Le Follet, I 856- I 857, print engraving on hand-colored paper: <http://hd. handle.net//0934/RM000 COLECT $483629>($ accessed 2021, Febraury 25).

Fig. 6. James Tissot, Evening, (n) Paris: Musée d'Orsay.
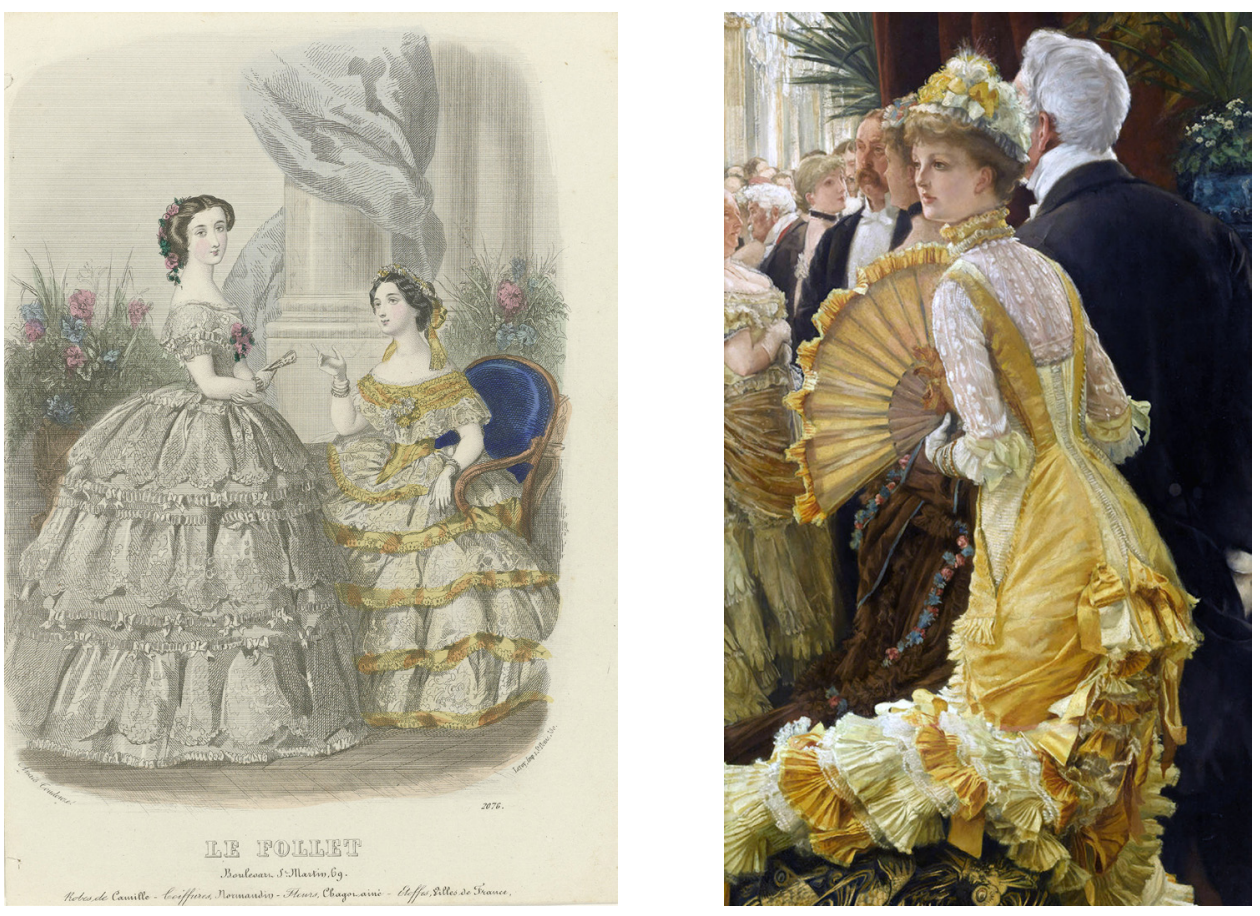
before the incursions of photography and modernist aesthetics which were to define the nature of fashion illustration in the twentieth century" [Breward 2003, p. I20]. If mass magazines offered relatively cheap access to representations of fashion glamour, while sacrificing quality, high society publications propagated luxury images by collaborating with renowned illustrators such as Adolphe-Charles Sandoz (1845-c. 1925) or renowned painters such as Jacques-Joseph Tissot (1836-1902) or Alfred Stevens (I823-1906) (fig. 6). Revolutionary attitudes instead characterize the representation of fashion in the following decades. The main reference of the illustrations were the avant-garde of haute couture rather than the commercial contents of traditional figurations. In the first decades of the twentieth century, the artistic figurative avant-gardes interact significantly with fashion illustration: the colour of the fabrics, the shaping of the clothes, the shape of the body and the materials used are

Fig. 7 Carl 'Eric' Erickson, Model with Broach \& Grey Tailleur, ink e gouache
on paper, $|89|-1958$. $<$ https://www grayma. com/collections/fashion(unstration> (accessed

Fig. 8. René Robert Bouché, Red Suit, 1950 watercolor and gouache on paper.
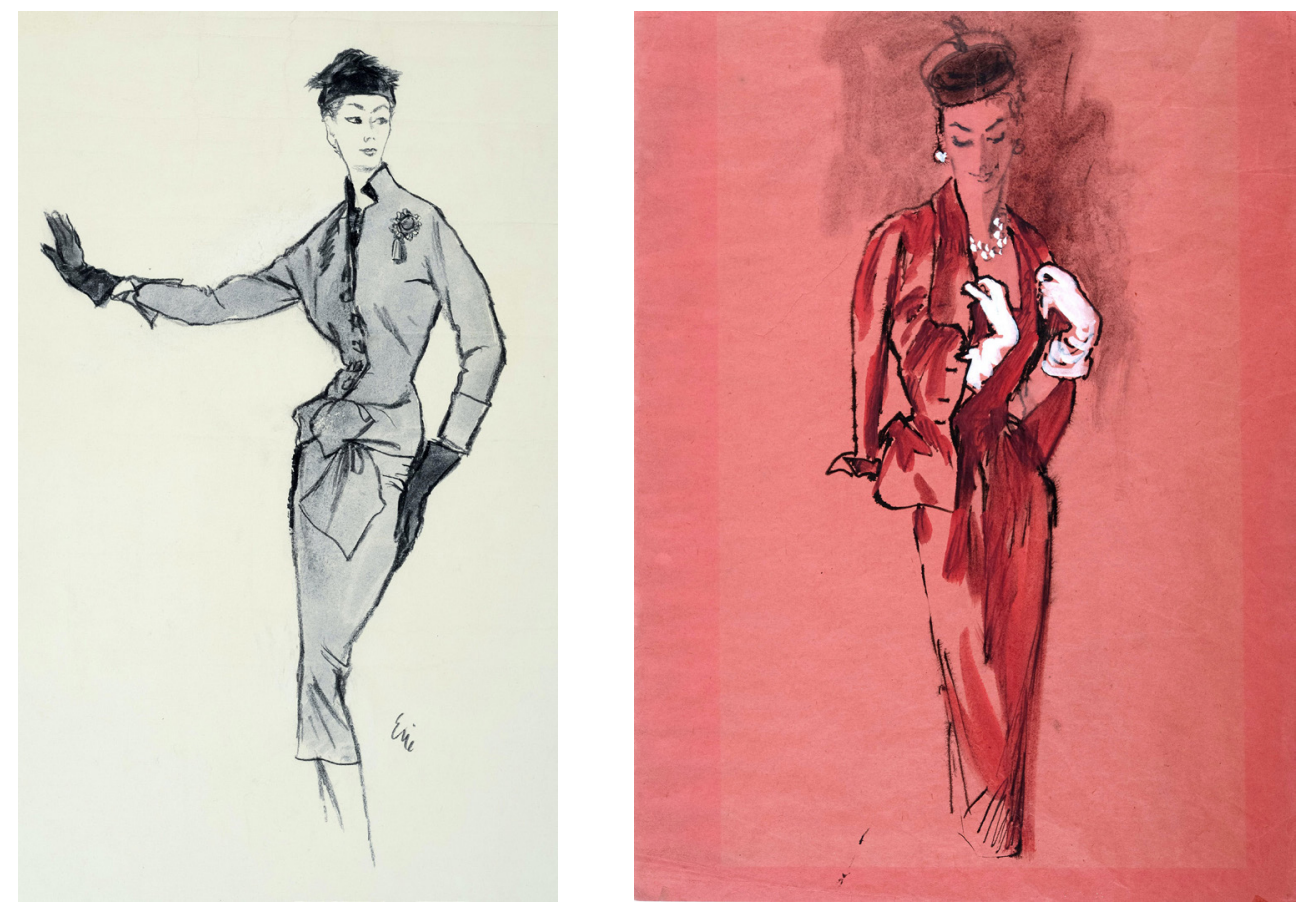

a mirror of the fauves, cubist, expressionist, futurist currents, dadaist and surrealist [Barnes 1994]. Art and illustration are in very close contact. But the real revolution in the world of twentieth-century fashion is brought about by photography. As early as the late nineteenth century, some periodicals began to replace illustrations with colour photographic images for promotional purposes [Robinson 1997]. And it is only the beginning of the climb of the new technique. In fact, if in the early years of its history, illustration in this field had the purpose of recording and communicating fashion trends, the growing importance given to photography somehow redefines its role, relegating it "to the creative realm of 'the dream"' [Breward 2003, p. 122]. Fashion illustration, although until the 1950s-1960s still retains a certain relevance, thanks to the talent of artists such as Carl Oscar August Erickson (I 89 |-1958), René Robert Bouché (1905-1963), André Édouard Marty (1882-1974), Eduardo Benito (I89 |198 I), Pierre Brissaud (1885-1964), René Bouët-Willaumez (1900-1979), Christian Bérard (1902-1949), (figs. 7-9) is gradually obscured by photography.

Many of the best-known photographers of the time revolutionized the representation of fashion through images that, drawing on the artistic experiences of contemporary avant-gardes, highlighted new identities between clothing and representation, much more effectively than drawn illustrations could do. Indeed, photographic images managed to satisfy the fash- 
Fig. 9. Eduardo Benito, illustrated cover for British Vogue, end of July 1926 : $<$ https://www.vogue. co.uk/fashion/gallery/ jewellery-images-vogue-archive > (accessed 2021 , February 25). ion industry's quest to accentuate the imaginative potential of lifestyle as a promotional tool, and it did so with a modern language capable of putting symbolism before materiality. Among the periodicals of the time, perhaps Vogue represents the most significant example of this passage [Breward 2003; Danielson 1986]. Published at the end of the nineteenth century in the United States, at the beginning of the twentieth century it was also widely distributed in Europe with editorial offices in various countries, supporting the idea of fashion

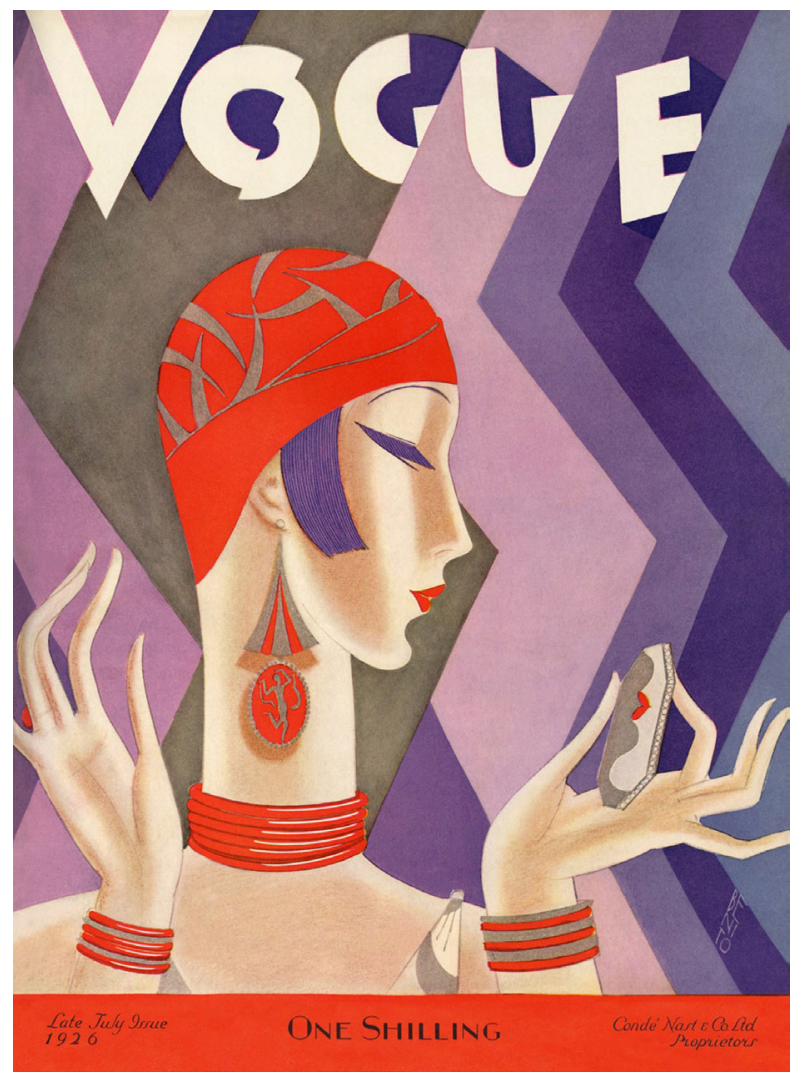

as a global phenomenon. As Breward noted, "Vogue capitalized on design innovations introduced in the production of European art magazines at the turn of the century, repackaging the fashion magazine as a desirable object in its own right, a harmonious and authoritative style guide that functioned as a bible for the fashion-conscious. Setting his horizons beyond the more parochial concerns of the old-style woman's magazine, Condé Nast looked to the philosophical and moral ideals of high modernism as a means of energizing the pages of his journal" [Breward 2003, p. 123]. Magazines such as Vogue and Harper's Bazaar stopped using drawings for their covers and the work of illustrators for fashion promotional purposes is less and less considered. As Packer noted, "After 1963, only one artist was commissioned by Vogue with any regularity at all. This was... Antonio [Lopez] whose published work over all those years, still amounts to rather less than that of Eric or Bouché, or indeed any of Vogue's former regulars, in any normal working year" [Packer 1983, pp. 173- 174]. Although there is a lack of individuality in the photographs, it is clear that the spaces of the illustration are reduced (fig. 10), partly due to a lack of imagination on the part of the readers, partly due to the capacity for identification inherent in photography: the consumer no longer buys from drawings [Danielson 1986]. 


\section{Conclusion}

Over time, fashion illustrations have represented a form of aesthetic expression which, while on the one hand has accompanied the strictly artistic activities, on the other has constituted one of the main ways of communicating aesthetic models to large social groups. The impact of fashion drawings on daily life has undoubtedly been significant, as is the surprising graphic documentation produced over the centuries by artists, illustrators and designers. The impulse given by illustration, however, has not only represented a method of communication and a tool of persuasion but has often had, through the hand of draftsmen-artists, also the purpose of building taste, becoming itself a fundamental element of design foreshadowing. The expressive side of illustration has important interactions both with the project and with communication and has shown in its historical evolution the ability to open up to new ways of looking at fashion. Intuition, creativity and imagination have characterized, in other words, the creative thinking of illustration. If the advent of photography represented the breakdown of a direct communication channel between drawing and consumer, it did not, however, affect the value of the same as a design thought. However, it closed the window of imagination to the user in favour of an illusory reality.

This paper, therefore, intended to highlight the deep relationships between fashion drawing, technological development and communication, underlining the significant contribution made by this unique form of illustration to the history of fashion, costume, but also to that of sociology and cultural anthropology.

Fig. 10. Antonio Lopez, Couture Spring: The Mood for Evening is Sinuous, Vogue, March 1973 : <hue, March 1973: com/article/antonio-lo com/article/antonio-losco-documentary-by-james-crump $>$ (accessed 2021, February 25).

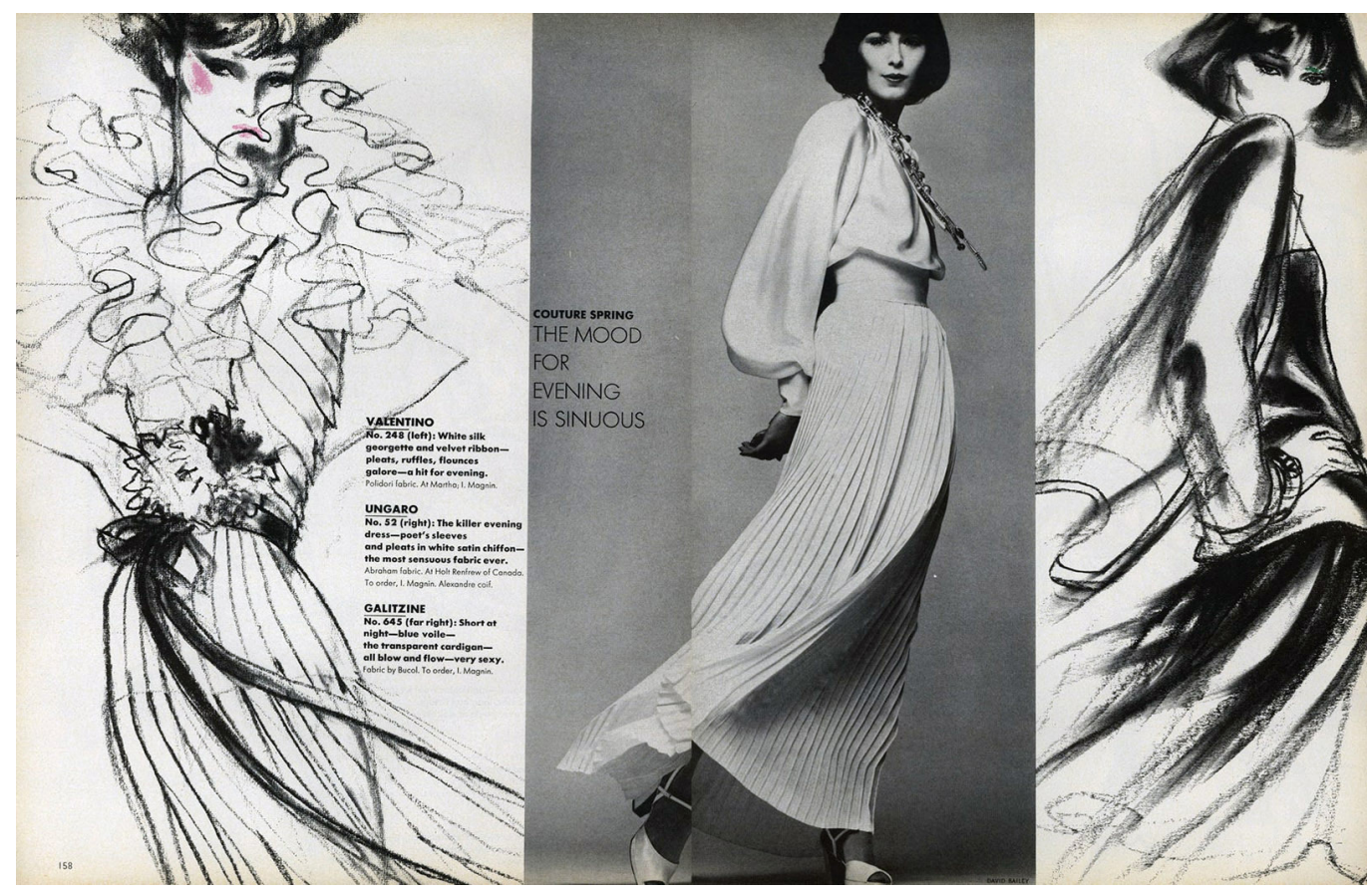

Notes

[1] Le Journal des dames et des modes, founded in 1797 and published in Paris by Pierre La Mesangere, was one of the first illustrated periodicals. The graphic repertoires, praised by the poet Baudelaire, were often elaborated by relevant engravers and artists such as Horace Vernet (1789-1836), Louis-Marie Lanté (1789-187|) [Simon 1995; Best 20 I7]. 


\section{References}

Anderson P. (1992). The printed image and the transformation of popular culture, 1790- 1860. New York: Clarendon Press of Oxford University Press.

Barnes C. (1994). Fashion Illustration. London: Little, Brown \& Co.

Barthes R. (1990). The Fashion system. Berkeley \& Los Angeles: University of California Press

Best K. N. (2017). The history of fashion journalism. Norfolk: Bloomsbury Publishing.

Breward C. (2003). Fashion. Hong Kong: Oxford University Press.

Brown J. (2002). Beyond the lines: Pictorial reporting, everyday life, and the crisis of gilded age America. Berkeley and Los Angeles: University of California Press.

Coleman E. J. (1990). Fashions as Seen Through Fashion Plates. In Vintage Fashions, vol. I (2), pp. 48-53.

Danielson D. R. ( 1986). According to the artists: Professional fashion illustrators' views about their art form. In Clothing and Textiles Research Journal, vol. 5 (I), pp. 27-33.

Danielson D. R. ( 1989). The changing figure ideal in fashion illustration. In Clothing and Textiles Research Journal, vol. 8 (I), pp. 35-48.

De Rubertis R. (2016). For history of scientific illustration. The case of the People's Zoological Atlas by dr. Giovanni Boschi. In XY digitale, L'immagine nella scienza e nell'arte, n. 2, pp. 80-91.

Mackrell A. (1997). An illustrated history of fashion: 500 years of fashion Illustration. New York: Costume \& Fashion Press.

Male A. (2017). Illustration:A theoretical and contextual perspective. New York: Bloomsbury Visual Arts.

Mirzoeff N. (1999). An introduction to visual culture. London: Routledge.

PackerW. (1983). Fashion drawing in Vogue. New York: Coward McCann.

Robinson J. (1997). The fine art of fashion: an illustrated history. Sydney: Murdoch Books.

Simon M. (1995). Fashion in art. The Second Empire and Impressionism. London: Zwemmer.

Stafford B.M. (|99|). Body criticism: imaging the unseen in enlightenment art and science. London: MIT Press.

\footnotetext{
Author

Stefano Chiarenza, Università San Raffaele Roma, stefano.chiarenza@uniroma5.it
}

To cite this chapter. Chiarenza Stefano (2021). L'illustrazione di moda tra arte, comunicazione e progetto/Fashion Illustration between Art, Communication And Project. In Arena A., Arena M., Mediati D., Raffa P. (a cura di). Connettere. Un disegno per annodare e tessere. Linguaggi Distanze Tecnologie. Atti del $42^{\circ}$ Convegno Internazionale dei Docenti delle Discipline della Rappresentazione/Connecting. Drawing for weaving relationship. Languages Distances Technologies. Proceedings of the $42^{\text {th }}$ International Conference of Representation Disciplines Teachers. Milano: FrancoAngeli, pp. 4| 4-43| 